\title{
Five new records and an identification key of the lichen genus Leptogium from Santa Catarina state, Brazil
}

\author{
Marcos Junji Kitaura ${ }^{1,4}$, Emerson Luiz Gumboski ${ }^{2} \&$ Ricardo Koroiva $^{3}$
}

\begin{abstract}
Leptogium is a cosmopolitan genus with currently 180 accepted species, of which 46 are reported from Brazil. Leptogium atlanticum, L. azureum, L. cyanescens, L. sessile and L. subjuressianum are recorded from the Brazilian state of Santa Catarina for the first time. Leptogium chloromelum var. crassius is synonymized with L. sessile. Leptogium atlanticum is recorded for the first time outside the type locality. We also provide comments and the first identification key for Leptogium species found in Santa Catarina state.
\end{abstract}

Key words: Ascomycota, Collemataceae, diversity, jelly lichen, taxonomy.

\section{Resumo}

Leptogium é um gênero cosmopolita com atualmente 180 espécies aceitas, das quais 46 são citadas para o Brasil. Leptogium atlanticum, L. azureum, L. cyanescens, $L$. sessile e $L$. subjuressianum são registradas aqui pela primeira vez para o estado de Santa Catarina. Leptogium chloromelum var. crassius é sinonimizado com L. sessile. Leptogium atlanticum é registrada pela primeira vez fora da localidade tipo. Nós também fornecemos comentários e a primeira chave de identificação para espécies de Leptogium encontradas no estado de Santa Catarina.

Palavras-chave: Ascomycota, Collemataceae, diversidade, liquens gelatinosos, taxonomia.

\section{Introduction}

Leptogium (Ach.) Gray is a jelly lichen genus with about 180 accepted species, though the monophyly remains questioned (Otálora et al. 2014). The species are cosmopolitan, occurring particularly in tropical regions, growing on various substrates and in several environments (Sierk 1964). Leptogium is characterized by its large, homoiomerous, foliose thallus, by distinct cortices with at least one well-defined cortical layer (eucortex), and its mainly epiphytic habit (Otálora et al. 2014). Recent studies suggest that the number of species ranges between 150 to 400 (Jayalal et al. 2014).

Fourty-six Leptogium species are actually accept to Brazil: L. adpressum Nyl., L. atlanticum Marcelli \& Kitaura, L. austroamericanum (Malme) C.W. Dodge, L. azureum (Sw.) Mont., L. brebissonii Mont., L. burgessii (L.) Mont., L. caespitosum (Taylor) Swinscow \& Krog, L. chloromelum
(Ach.) Nyl., L. cochleatum (Dicks.) P.M. Jørg. \& James, L. coralloideum (Meyen \& Flot.) Vain., $L$. corticola (Taylor) Tuck., L. cyanescens (Rabenh.) Körb., L. decipiens P.M. Jørg., L. denticulatum Nyl., L. diaphanum Mont., L. dimorphum Müll. Arg., L. foveolatum Nyl., L. fusisporum (Tuck.) C.W. Dodge, L. hibernicum M.E. Mitch. ex P.M. Jørg., L. involutum Kitaura, Käffer \& Martins, $L$. isidiosellum (Riddle) Sierk, L. javanicum Mont., L. kalbii Marcelli \& Cunha, L. laceroides Degel., L. lafayetteanum Vain., L. longisporum Kitaura \& Marcelli, L. mantiqueirense Kitaura \& Marcelli, $L$. marginellum (Sw.) Gray, L. mattogrossense Malme, L. megapotamicum Malme, L. moluccanum (Pers.) Vain., L. pachycheilum Malme, L. phyllocarpum Mont., L. pichneum (Ach.) Nyl., L. puiggarii Müll. Arg., L. punctulatum Nyl., L. reticulatum Mont., $L$. schiffneri Zahlbr., L. sessile Vain., L. sphinctrinum Nyl., L. stipitatum Vain., L. subbullatum Kremp., $L$. subjuressianum Marcelli \& Kitaura, L. tuckermanii

\footnotetext{
${ }^{1}$ Universidade Federal de Mato Grosso do Sul, PPG em Biologia Vegetal, Cidade Universitária s/n, 79070-900, Campo Grande, MS, Brazil. junjimjk@gmail. com

${ }^{2}$ Universidade da Região de Joinville, Depto. Ciências Biológicas, R. Paulo Malschitzki 10, Zona Industrial Norte, 89219-710, Joinville, SC, Brazil. emersongumboski@gmail.com

${ }^{3}$ Universidade Federal de São Carlos, PPG em Ecologia e Recursos Naturais, Rod. Washington Luís km 235, SP-310, 13565-905, São Carlos, SP, Brazil. ricardo.koroiva@gmail.com

${ }^{4}$ Author for correspondence: junjimjk@gmail.com
} 
C.W. Dodge, L. ulvaceum Vain. and L. vesiculosum (Sw.) Malme (Krempelhuber 1876; Vainio 1890; Malme 1924; Osorio 1977a; Osorio 1977b; Aptroot 2002; Spielmann 2006; Cunha 2007; Käffer et al. 2007; Gumboski \& Eliasaro 2011; Kitaura 2012; Kitaura \& Marcelli 2012; Kitaura \& Marcelli 2013; Benatti et al. 2013; Kitaura et al. 2013a; Kitaura et al. 2013b; Aptroot \& Cáceres 2014; Kitaura et al. 2014; Cáceres et al. 2014; Kitaura et al. 2015).

In the Southern Brazil, nine species were recorded for the Paraná state (Eliasaro \& Gumboski, pers. comm.), and 19 species for the Rio Grande do Sul state (Spielmann 2006), but the vast majority of these were recorded only from a few localities.

For the Santa Catarina state, Gumboski \& Eliasaro (2011) reported 11 Leptogium species. Despite this number, during recent field campaigns specimens representing five new records were sampled: L. atlanticum, L. azureum, L. cyanescens,
L. sessile and L. subjuressianum, increasing the number of Leptogium species known in the state with $45 \%$. We hereby present these new records with comments and include L. chloromelum var. crassius in the synonymy of $L$. sessile. In addition, we provide the first identification key for Leptogium species found in Santa Catarina.

We collected samples during lichenological field work on several sites in eastern Santa Catarina state (municipalities of São Francisco do Sul and São Bento do Sul). They were deposited in the Universidade Federal de Mato Grosso do Sul Herbarium (CGMS). Moreover, we analyzed all specimens according to the protocol of Kitaura (2012) and Kitaura \& Marcelli (2012; 2013).

Lichen photographs were taken with a Scanjet 5590 and by the Canon RebelT3i coupled on Olympus Sz stereomicroscopy and Olympus CX22LED microscopy.

\section{Identification key to Leptogium in Santa Catarina state, Brazil}

1. Thallus with hairs

2. Hairs constituted by spherical cells Leptogium burgessii

2'. Hairs constituted by cylindrical cells Leptogium subjuressianum

1'. Thallus without hairs 3

3. Thallus with smooth to slightly rugose upper surface ….................................................. 4

4. Thallus with ornaments on the lamina and margin 5

5. Ornaments usually cylindrical (isidia) Leptogium cyanescens

5'. Ornaments usually flattened and rotund (lobules) Leptogium atlanticum

4'. Thallus without ornaments on the lamina and margin

6. Thallus with apothecia subpedicellate or adnate

6'. Thallus with apothecia pedicellate (ascending by the thallus)

7. Pedicel long (more than $0.5 \mathrm{~mm}$ ), inflated

7'. Pedicel short (to $0.5 \mathrm{~mm}$ long), not inflated

8. Thallus is colored bluish and 70-100 $\mu \mathrm{m}$

Leptogium moluccanum

8'. Thallus is colored greyish and 100-150 $\mu \mathrm{m}$

3'. Thallus with upper surface with ridges, wrinkles or foveolate Leptogium cochleatum

9. Thallus with foveolate surface 9

9'. Thallus with upper surface ridged or wrinkled Leptogium foveolatum

10. Ornaments present on the thallus and/or apothecia 10

11. Ornaments on the thallus and apothecia 12. Upper surface has wrinkles 12'. Upper surface has ridges 11

11 '. Ornaments only on the apothecia Leptogium isidiosellum

13. Thallus with marginal apothecia 13

13'. Thallus with submarginal or laminal apothecia .... Leptogium phyllocarpum

10'. Ornaments absent

14. Apothecia pedicellate (more than $0.5 \mathrm{~mm}$ ) Leptogium vesiculosum

14'. Apothecia sessile, immerse and adnate

15. Apothecia immerse, ascospores muriform to submuriform ... Leptogium sessile 15'. Apothecia adnate, ascospores transversally septate ..... Leptogium adpressum 
Leptogium atlanticum Marcelli \& Kitaura, The Bryologist, 118(1): 12. 2015.

Type: BRAZIL. SÃO PAULO: Municipality of Peruíbe, Reserva Ecológica Juréia-Itatins. Núcleo Guarauzinho, Sopé da Serra, Arpoador Beach, on rock, 27.VII.1993, M.P. Marcelli \& O. Yano 23710 (holotype: SP!; isotypes: COLO!, H!).

Description and illustrations of the holotype: Kitaura et al. (2015).

Leptogium atlanticum is characterized by lobulated thallus, the smooth to rugulose upper surface, the elongated or rotund lobules on the lamina and margin, and the medulla is constituted of helicoidal columnar hyphae. Initially, we identified L. atlanticum as L. denticulatum, but that species differs from the first one by the presence of irregular lobules on the thallus (Kitaura et al. 2015).

We collected our specimens on trunks of restinga shrubs.

Distribution: This species had been reported only for São Paulo state, Brazil, where it was sampled on different substrata, from the beach to mangroves and rainforest on the coastal slopes (Kitaura et al. 2015).

Material examined: São Francisco do Sul, Parque Estadual do Acaraí, 26¹7'28.6”S, 48³2'15.8'W, alt. 6 m, on trunk, 6.X.2015, M.J. Kitaura $2619 \& 2637$ (CGMS).

Leptogium azureum (Sw.) Mont. Hist. Nat. Iles Canar. 3: 129. 1840.

Type: JAMAICA: on the Mountains, O. Swartz $s / n$. (lectotype: UPS; isolectotype: BM000963630!, designed by Jørgensen \& James 1983).

$\equiv$ Lichen azureus Sw. ap. Ach., Lichenog. Suec. Prodr.: 137. 1798.

EParmelia azurea Ach., Meth. Lich.: 223. 1803.

三 Collema azureum Ach., Lich. Univ.: 654. 1810.

= Collema tremelloides var. azureum Eschw. in Mart., Fl. bras. 1: 237. 1833.

=Leptogium tremelloides var. azureum (Sw.) Nyl., Syn. Lich. 1: 125. 1858.

Description and illustrations of the holotype: Aragón et al. (2004) and Kitaura (2012).

Leptogium azureum is characterized by its bluish color, smooth upper surface and pedicellated apothecia. This species is complex and necessitates further taxonomical studies.

The species occurs on trunks of restinga shrubs, and on trunks of Araucaria forest.

Distribution: Leptogium azureum is a species occurring across the globe (Aragón et al. 2004).
In Brazil, there are records for the states of Mato Grosso, Minas Gerais, Pará, Paraná, Rio de Janeiro, Rio Grande do Sul and São Paulo (Krempelhuber 1876; Brako et al. 1985; Aptroot 2002; Carbonero et al. 2003; Aragón et al. 2004; Spielmann 2006 Cunha 2007).

Material examined: São Bento do Sul, APA do Rio Vermelho-Humboldt, Araucaria Forest, corticolous, 6.IX.2012, E. Gumboski 3909 \& 3910; 31.X.2013, E. Gumboski 4959. São Francisco do Sul, Parque Estadual do Acaraí, 26¹7'28.6”S, 48³2'15.8'W, alt. 6 m., on trunk, 6.X. 2015, M.J. Kitaura 2578, 2585, 2601, 2604 \& 2614 .

Leptogium cyanescens (Rabenh.) Körb, Syst. Lich.: 420. 1855.

Type: SWITZERLAND. HELVETIA: no. 757. (lectotype: H-ACH 1913!, designated by Galloway \& Jørgensen 1995).

三 Collema cyanescens Rabenh., Deutsch. Krypt. F1.: 50. 1845.

= Collema tremelloides var. cyanescens Ach., Syn. Meth. Lich.: 326. 1814. nom. illeg.

=Leptogium caesium (Ach.) Vain., Acta Soc. Fauna \& Flora Fenn. 7A: 225. 1890.

= Collema tremelloides var. caesium Ach., Lich. Univ.: 656. 1810.

Description and illustrations of the holotype: Goward et al. (1994), McCune \& Geiser (1997), Brodo et al. (2001), Stone \& Ruchty (2007) and Kitaura (2012).

Leptogium cyanescens differs from other Leptogium species through its blue-grey color, smooth upper surface, thin and rounded lobes, and its cylindrical and delicate isidia emerging as small whitish papillae on the upper surface and along the margins.

Our specimens were collected off the trunks of mangroves and shrubs of restinga.

Distribution: Leptogium cyanescens is a species with a global distribution. In Brazil, there are records for the states of Sergipe, Minas Gerais, Paraná, Rio de Janeiro, Rio Grande do Sul and São Paulo (Krempelhuber 1876; Osorio 1977a; Osorio 1977b; Aptroot 2002; Spielmann 2006; Cunha 2007; Cáceres et al. 2014).

Material examined: São Francisco do Sul, Campus of Universidade da Região de Joinville (Univille), $26^{\circ} 12$ '53.2"S, 48 34'27.7' W, alt. $2 \mathrm{~m}$, on trunk, 5.X.2015, M.J. Kitaura 2561, 2568, $2570 \& 2571$; Parque Estadual do Acaraí, 26¹7'28.6”'S, 48³2'15.8”W, alt. 6 $\mathrm{m}$, on trunk, restinga, 6.X.2015, M.J. Kitaura 2583, 2609, 2610, 2612 \& 2621; 26²2'04.2'S, 48³4'13'W, 29.III.2009, E. Gumboski \& S. Eliasaro 1418b. 
Leptogium sessile Vain., Ann. Acad. Sci. Fenn. ser. A IV Biologica 6(7): 108. $1915 . \quad$ Fig. 1a-e Type: DOMINICA(WEST INDIA). SHAWFORD STATE: ad corticem arboris, 1896, W.R. Elliott 1594p.p. (holotype: TUR-V 10791!; isotype: TUR-V 10792!).

Fig. 1a,d,e
=Leptogium chloromelum var. crassius Nyl., Bull. Soc. Linn. Norm. 3(2): 5. 1869. Type: SOUTH AFRICA. DURBAN: Port-Natal, Miss Armstrong $s / n$. (holotype: H-NYL 41253!).

Fig. 1b,c Description and illustrations of the holotype: Vainio (1915), Sierk (1964) and Kitaura (2012).
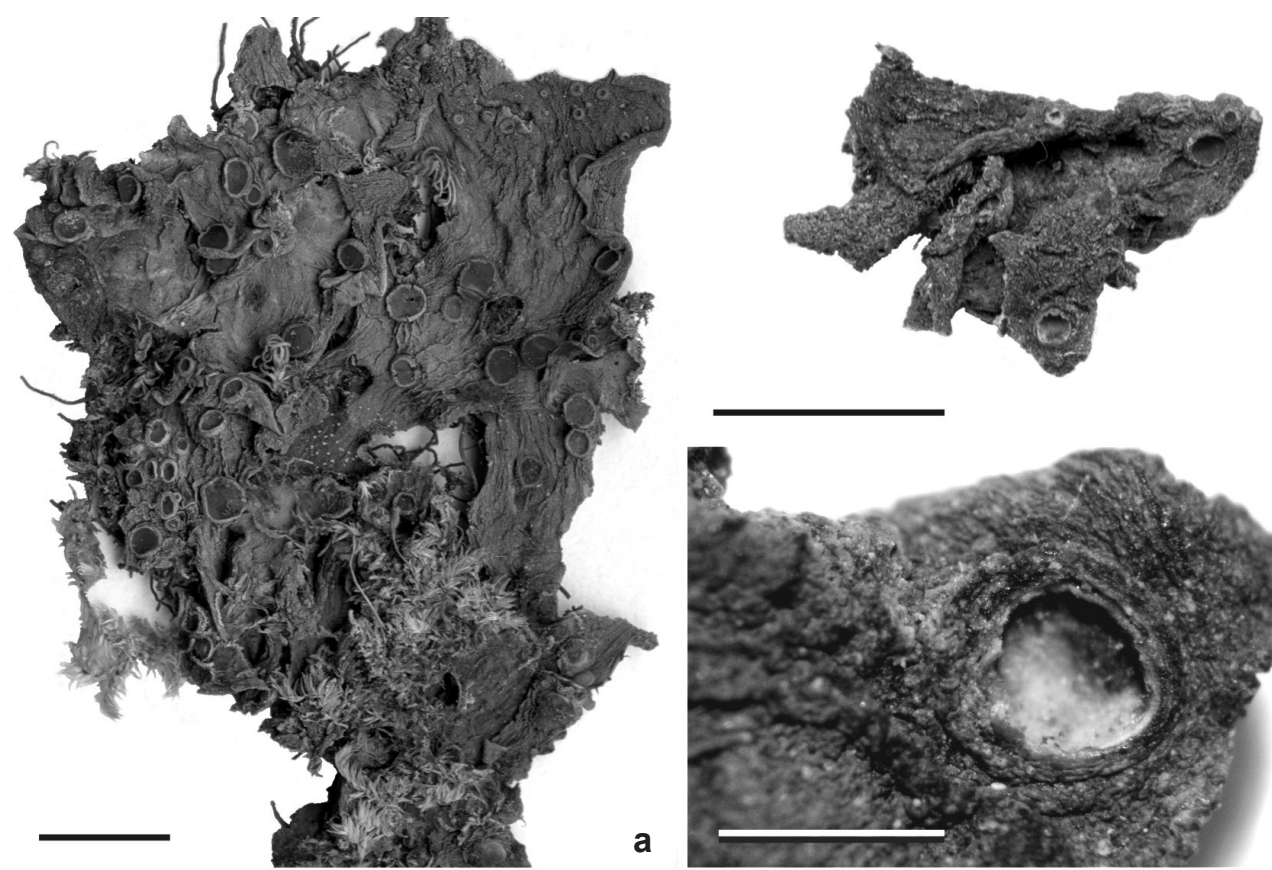

b
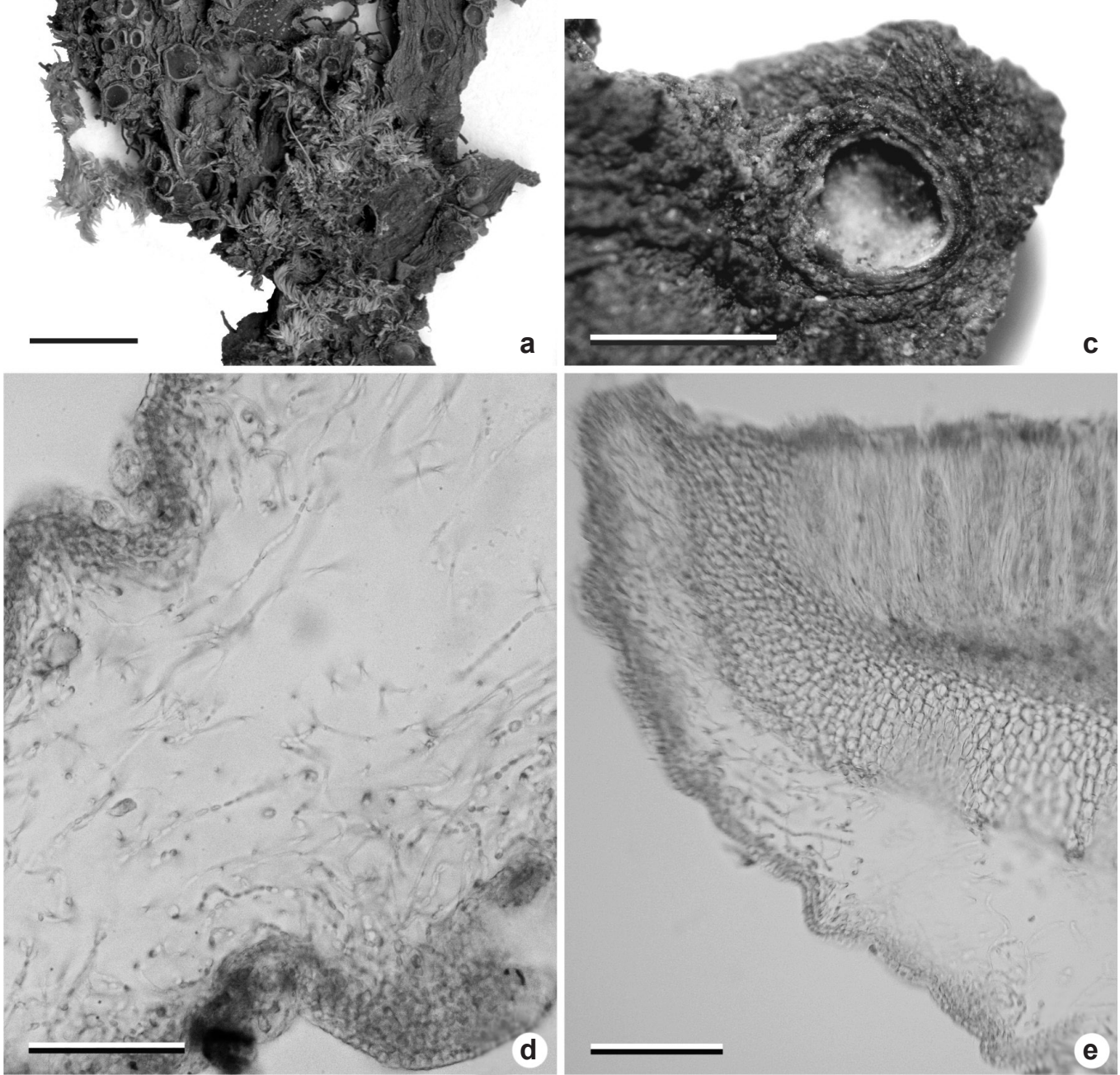

Figure 1 - a-e. Leptogium species - a. L. sessile holotype (TUR-V 10791); b. L. chloromelum var. crassius holotype (holotype: H-NYL 41253); c. Apothecia detail of L. chloromelum var. crassius; d. Transversal section of L. sessile thallus; e. Transversal section of $L$. sessile apothecia. Scale bars: $\mathrm{a}, \mathrm{b}=5 \mathrm{~mm} ; \mathrm{c}=1 \mathrm{~mm} ; \mathrm{d}=50 \mu \mathrm{m} ; \mathrm{e}=100 \mu \mathrm{m}$. 
Leptogium sessile is characterized by its thickened thallus (115-190 $\mu \mathrm{m}$ thick), rugulose and wrinkled longitudinal lobes, as well as its immersed to sessile apothecia and amphithecium with circular ridges (Fig. 1c).

Leptogium chloromelum var. crassius was included in the list of synonyms of $L$. sessile after studying the type. The type $L$. chloromelum var. crassius (H-NYL 41253) is identical to the distal parts of the holotype of L. sessile (TUR-V 10791).

Vainio (1915) studied the material collected by W.R. Elliott and described $L$. sessile without mentioning the collector number. Later, Sierk (1964) reviewed the material studied by Vainio and considered W.R. Elliott's material (now TUR-V 10791) as lectotype during a study of Leptogium species from USA and Mexico.

Even so, Jørgensen found other material in the same herbarium: W.R. Elliott 1594 p.p. (TUR-V 11792), which had been identified as L. phyllocarpum. Jørgensen concluded that the TUR-V 11792 material is an isotype of the $L$. sessile and reported this fact on an annotation label, but he did not publish his discovery. During a visit to the Turku herbarium, this TUR-V 11792 material was analyzed and we found these comments on the labels with the material.

We collected these specimens on trunk of restinga shrubs.

Distribution: Leptogium sessile is a species with global distribution. In Brazil, there are state records for Rio Grande do Sul (Spielmann 2006) and São Paulo (Aptroot 2002).

Material examined: São Francisco do Sul, Parque Estadual do Acaraí, $26^{\circ} 17^{\prime} 28.6^{\prime \prime} \mathrm{S}, 48^{\circ} 32^{\prime} 15.8^{\prime \prime} \mathrm{W}$, alt. 6 m, on trunk, restinga, 6.X.2016, M.J. Kitaura 2590; 7.X.2016, M.J. Kitaura 2640.

Leptogium subjuressianum Marcelli \& Kitaura, Mycotaxon 120: 218. 2012.

Type: BRAZIL. RIO GRANDE DO SUL: Municipality of Tapes, on trunk of a tree, $5 \mathrm{~m}$ alt., 29.I.1994, M.P. Marcelli 26459 (holotype: SP!).

Description and illustrations of the holotype: Kitaura \& Marcelli (2012).

Leptogium subjuressianum is distinguishable according to its spongioid hairs on upper surface and rounded lobules on the margin of the thallus.

This specimen was collected on trunk of Araucaria forest.

Distribution: Leptogium subjuressianum is common in Brazil and usually collected from surfaces of tree trunks. The species has been collected from Tapes Municipality, Rio Grande do
Sul state, to Alto Caparaó Municipality in Minas Gerais state (Kitaura \& Marcelli 2012).

Material examined: São Bento do Sul, APA do Rio Vermelho-Humboldt, Araucaria Forest, corticolous, 16.II.2013, E. Gumboski 4239b.

\section{Acknowledgments}

The authors thank the curators of BM, COLO, H, SP, TUR \& UPS for their effective and timely support, and the reviewers. M.J.K. and R.K. thank the CAPES for their scholarships.

\section{References}

Aptroot A (2002) New and interesting lichens and lichenicolous fungi in Brazil. Fungal Diversity 9:15-45.

Aptroot A \& Cáceres MES (2014) A key to the corticolous microfoliose, foliose and related crustose lichens from Rondônia, Brazil, with the description of four new species. Lichenologist 46: 783-799.

Aragón G, Martínez I \& Otálora MAG (2004) New data on the distribution of Leptogium azureum (Sw.) Mont. Lichenologist 36: 345-347.

Benatti MN, Kitaura MJ, Dias IPRC \& Marcelli MP (2013) Cianoliquens dos gêneros Coccocarpia, Collema e Leptogium do Parque Estadual da Cantareira, SP, Brasil, depositados no herbário SP. Hoehnea 40: 131-141.

Brako L, Dibben MJ \& Amaral I (1985) Preliminary notes on the macrolichens of Serra do Cachimbo, northcentral Brazil. Acta Amazonica 15: 123-135.

Brodo IM, Sharnoff SD \& Sharnoff S (2001) Lichens of North America. Yale University Press, New Haven. 795p.

Cáceres MES, Lima EL, Aptroot A \& Lücking R (2014) Liquens brasileiros: novas descobertas evidenciam a riqueza no Norte e Nordeste do país. Boletim do Museu de Biologia Mello Leitão 35: 101-119.

Carbonero ER, Tischer CA, Cosentino C, Gorin PAJ \& Iacomini M (2003) Structural characterization of a galactomannan from the cyanolichen Leptogium azureum. Carbohydrate Polymers 53: 469-473.

Cunha IPR (2007) Fungos liquenizados do gênero Leptogium (Ascomycetes) no litoral sul do estado de São Paulo. Master dissertation. Universidade Estadual Paulista "Júlio de Mesquita Filho", Botucatu. 114p.

Galloway DJ \& Jørgensen PM (1995) The lichen genus Leptogium (Collemataceae) in southern Chile, South America. In: Daniels FJA, Schulz M \& Peine $\mathrm{J}$ (eds.) Contributions to lichenology in honour of Gerhard Follmann. Botanical Institute University of Cologne, Cologne. Pp. 227-247.

Goward T, McCune B \& Meidinger D (1994) The lichens of British Columbia. Illustrated keys. Part 1. 
Foliose and squamulose species. Ministry of Forests Research Program. Special Report Series 8:1-181.

Gumboski EL \& Eliasaro S (2011) Checklist of lichenized fungi of Santa Catarina state (Brazil). Mycotaxon 115: 535.

Jayalal U, Jang SH, Yu NH, Oh SO \& Hur JS (2014) Notes on the lichen genus Leptogium (Collemataceae, Ascomycota) in South Korea. Mycobiology 42: 120-131.

Jørgensen PM \& James PW (1983) Studies on some Leptogium species of Western Europe. Lichenologist 15: 109-125.

Käffer MI, Ganade G \& Marcelli MP (2007) Interação entre liquens e forófitos em quarto ambientes na FLONA de São Francisco de Paula. Revista Brasileira de Biociências 5: 216-218.

Kitaura MJ (2012) Estudos taxonômicos de Leptogium (Ach.) S.F. Gray (Collemataceae, fungos liquenizados). $\mathrm{PhD}$ thesis. Universidade Estadual Paulista "Júlio de Mesquita Filho", Botucatu. 249p.

Kitaura MJ \& Marcelli MP (2012) The Leptogium juressianum complex in southeastern Brazil. Mycotaxon 120: 215-221.

Kitaura MJ \& Marcelli MP (2013) A revision of Leptogium species with spherical-celled hairs (section Mallotium p.p.). The Bryologist 116: 15-27.

Kitaura MJ, Marcelli MP, Hora BR \& Jungbluth P (2013a) A new non-isidiate Leptogium species with transverse septate ascospores from Southeastern Brazil. Mycosphere 4: 986-992.

Kitaura MJ, Marcelli MP, Jungbluth P \& Hora BR (2013b) Five supposedly well-known species of Leptogium section Mallotium. Mycosphere Online - Journal of Fungal Biology 4: 520-530.

Kitaura MJ, Käffer MI, Marcelli MP \& Martins SMA (2014) A new hairy Leptogium (section Mallotium) from Rio Grande do Sul state, Brazil. Hoehnea 41: 303-306.

Kitaura MJ, Marcelli MP, Hora BR \& Jungbluth P (2015) Leptogium denticulatum (Collemataceae, lichenized Ascomycota) and some morphologically related species. The Bryologist 118: 11-21.

Krempelhuber A (1876) Lichenes brasilienses collecti a D.A. Glaziou in provincia brasiliensi Rio Janeiro. Flora 59: 56-63.

Malme GOA(1924) Die Collematazeen des Regnellschen Herbars. Arkiv Für Botanik 19: 1-29.

McCune B \& Geiser L (1997) Macrolichens of the Pacific Northwest. Oregon State University Press, Corvallis. 449p.

Osorio H (1977a) Contribution to the lichen flora of Brazil II Lichenes from Guarapava, Paraná state. Dusenia 10: 101-102.

Osorio H (1977b) Contribution to the lichen flora of Brazil III Lichenes from Western Paraná. Acta Biologica Paranaense 6: 3-7.

Otálora MAG, Jørgensen PM \& Wedin M (2014) A revised generic classification of the jelly lichens, Collemataceae. Fungal Diversity 64: 275-293.

Sierk HA (1964) The genus Leptogium in North America North of Mexico. The Bryologist 67: 245-317.

Spielmann AA (2006) Checklist of lichens lichenicolous fungi of Rio Grande do Sul (Brazil). Caderno de Pesquisa Série Biologia 18: 7-125.

Stone DF \& Ruchty A (2007) Leptogium cyanescens - a catchall name for gray isidiate Leptogium species in the pacific Northwest? Available in $<$ http://www. fs.fed.us/r6/sfpnw/issssp $>$. Access on 26 September 2016.

Vainio EA (1890) Étude sur la classification naturalle et la morphologie des lichens du Brésil. Acta Societatis Pro Fauna et Flora Fennica 7: 1-256. 